\title{
Bacillus cibi sp. nov., isolated from jeotgal, a traditional Korean fermented seafood
}

Correspondence

Jung-Hoon Yoon

jhyoon@kribb.re.kr

\author{
Jung-Hoon Yoon, Choong-Hwan Lee and Tae-Kwang Oh \\ Korea Research Institute of Bioscience and Biotechnology (KRIBB), PO Box 115, Yusong, \\ Taejon, Korea
}

\begin{abstract}
A Gram-variable, motile, endospore-forming, halotolerant bacillus, strain $\mathrm{JG}-30^{\top}$, was isolated from the traditional Korean fermented seafood jeotgal, and was subjected to a polyphasic taxonomic study. This organism grew optimally at $37^{\circ} \mathrm{C}$ and in the presence of $0-1 \%(\mathrm{w} / \mathrm{v}) \mathrm{NaCl}$. $16 \mathrm{~S}$ rRNA gene sequence analysis showed that strain $\mathrm{JG}-30^{\top}$ forms a distinct phylogenetic lineage within the evolutionary radiation encompassed by the genus Bacillus. Strain JG- $30^{\top}$ was characterized chemotaxonomically as having cell-wall peptidoglycan based on meso-diaminopimelic acid, MK-7 as the predominant menaquinone and iso- $\mathrm{C}_{15: 0}$ and iso- $\mathrm{C}_{14: 0}$ as the major fatty acids. The DNA G + C content was 45 mol\%. Strain JG-30 ${ }^{\top}$ exhibited levels of $16 \mathrm{~S}$ rRNA gene sequence similarity of less than $95 \cdot 7 \%$ to Bacillus species with validly published names. On the basis of its phenotypic properties and phylogenetic distinctiveness, strain JG- $30^{\top}$ ( $=\mathrm{KCTC}$ $3880^{\top}=$ DSM $16189^{\top}$ ) was classified within the genus Bacillus as a novel species, for which the name Bacillus cibi sp. nov. is proposed.
\end{abstract}

Studies on the microbiota of jeotgal, a traditional Korean fermented seafood, have shown that the majority of isolates are Gram-positive or Gram-variable, endospore-forming bacilli (Yoon et al., 2001a, b). Some new genera or species have been isolated from jeotgal (Yoon et al., 2001a, b, 2003a, b). In this study, we report on the taxonomic characterization of a halotolerant, orange/yellow-pigmented Bacilluslike bacterial strain, JG-30 ${ }^{\mathrm{T}}$, which was isolated from jeotgal.

Strain $\mathrm{JG}-30^{\mathrm{T}}$ was isolated by means of the usual dilution plating technique on marine agar 2216 (MA; Difco) at $30^{\circ} \mathrm{C}$. The cell morphology was examined by light microscopy (model E600; Nikon) and transmission electron microscopy. The flagellum type was also examined by transmission electron microscopy (model CM-20; Philips) using cells from exponentially growing cultures. The Gram reaction was determined using the bioMérieux Gram stain kit according to the manufacturer's instructions. Growth under anaerobic conditions was determined after incubation in an anaerobic chamber with MA that had been prepared anaerobically using nitrogen. Growth in the absence of $\mathrm{NaCl}$ was investigated in trypticase soy broth without $\mathrm{NaCl}$. Growth at various $\mathrm{NaCl}$ concentrations was investigated in marine broth 2216 (MB; Difco) or trypticase soy broth. Growth at various temperatures $\left(4-50{ }^{\circ} \mathrm{C}\right)$ was measured on MA. Catalase and oxidase activities and the hydrolysis of casein, gelatin, hypoxanthine,

Published online ahead of print on 5 November 2004 as DOI 10.1099/ ijs.0.63208-0.

The GenBank/EMBL/DDBJ accession number for the 16S rRNA gene sequence of strain $\mathrm{JG}-30^{\top}$ is $A Y 550276$. starch, Tween 80, tyrosine and xanthine were tested for as described by Cowan \& Steel (1965). Hydrolysis of aesculin, Voges-Proskauer and methyl red reactions and nitrate reduction were determined as described by Lanyi (1987). $\mathrm{H}_{2} \mathrm{~S}$ production was tested for as described previously (Bruns et al., 2001). Acid production from carbohydrates was determined as described by Leifson (1963). Utilization of substrates as sole carbon and energy sources was tested as described by Baumann \& Baumann (1981) using supplementation with $2 \%(\mathrm{v} / \mathrm{v})$ Hutner's mineral base (CohenBazire et al., 1957) and $1 \%(\mathrm{v} / \mathrm{v})$ vitamin solution (Staley, 1968). Enzyme activity was determined by using the API ZYM system (bioMérieux). Other physiological and biochemical tests were performed with the API 20E system (bioMérieux).

Cell biomass for analyses of the cell-wall peptidoglycan and isoprenoid quinones and for DNA extraction was obtained from cultivation in $\mathrm{MB}$ at $37^{\circ} \mathrm{C}$. The isomer type of the diamino acid of the cell-wall peptidoglycan was determined by the method of Komagata \& Suzuki (1987). Isoprenoid quinones were extracted and analysed as described previously (Komagata \& Suzuki, 1987) using reversed-phase HPLC. For fatty acid methyl ester analysis, a loop of cell mass was harvested from agar plates after cultivation for 2 days at $37^{\circ} \mathrm{C}$ on MA. The fatty acid methyl esters were extracted and prepared according to the standard protocol of the MIDI/ Hewlett Packard Microbial Identification System (Sasser, 1990). Chromosomal DNA was isolated and purified according to the method described previously (Yoon et al., 1996), with the exception that ribonuclease $\mathrm{T} 1$ was used together with ribonuclease A. The DNA G $+\mathrm{C}$ content was 
determined by the method of Tamaoka \& Komagata (1984), with the modification that DNA was hydrolysed and the resultant nucleotides were analysed by reversed-phase HPLC. The 16S rRNA gene was amplified by a PCR using two universal primers, as described previously (Yoon et al., 1998). Sequencing of the amplified 16S rRNA gene and phylogenetic analysis were performed as described by Yoon et al. (2003a).

The morphological, physiological and biochemical characteristics of strain JG- $30^{\mathrm{T}}$ are shown in Table 1 or are given in the species description (see below). Strain JG-30 $0^{\mathrm{T}}$ contained meso-diaminopimelic acid as the diamino acid in the cell-wall peptidoglycan and it had an unsaturated menaquinone with seven isoprene units (MK-7) as the predominant isoprenoid quinone. The cellular fatty acid profile showed a large amount of branched fatty acids; the major components were iso- $\mathrm{C}_{15: 0}$ $(31 \cdot 8 \%)$, iso- $\mathrm{C}_{14: 0}(26 \cdot 7 \%)$, iso- $\mathrm{C}_{16: 0}(15 \cdot 6 \%)$ and anteiso$\mathrm{C}_{15: 0}(15 \cdot 4 \%)$. The DNA G $+\mathrm{C}$ content of strain JG- $30^{\mathrm{T}}$ was $45 \mathrm{~mol} \%$. An almost-complete $16 \mathrm{~S}$ rRNA gene sequence of strain JG-30 ${ }^{\mathrm{T}}$ comprising $1493 \mathrm{nt}$ (approx. $96 \%$ of the Escherichia coli $16 \mathrm{~S}$ rRNA sequence) was determined directly after PCR amplification. Phylogenetic analyses based on 16S

Table 1. Phenotypic characteristics of Bacillus cibi sp. nov. and some related Bacillus species

Species: 1, B. cibi sp. nov.; 2, B. cohnii, data from Spanka \& Fritze (1993) and Suresh et al. (2004); 3, B. halmapalus, data from Nielsen et al. (1995) and Suresh et al. (2004); 4, B. cereus, data from Claus \& Berkeley (1986) and Priest et al. (1988); 5, B. simplex, data from Priest et al. (1988) and De Clerck et al. (2004); 6, B. megaterium, data from Claus \& Berkeley (1986), Reva et al. (2002) and Täubel et al. (2003); 7, B. psychrosaccharolyticus, data from Priest et al. (1988) and Suresh et al. (2004); 8, B. fastidiosus, data from Claus \& Berkeley (1986); 9, B. jeotgali, data from Yoon et al. (2001a). +, Positive reaction; -, negative reaction; ND, not determined; NG, no growth; V, variable reaction. Data in parentheses are for the type strain. All species are rods and catalase-positive.

\begin{tabular}{|c|c|c|c|c|c|c|c|c|c|}
\hline Characteristic & 1 & 2 & 3 & 4 & 5 & 6 & 7 & 8 & 9 \\
\hline Spore shape $e^{\star}$ & E & $\mathrm{E}$ & E & E & $\mathrm{E}$ or $\mathrm{C}$ & $\mathrm{E}$ & E & E & E \\
\hline Spore position $\dagger$ & $\mathrm{C}$ or $\mathrm{S}$ & $\mathrm{T}$ & $\mathrm{P}$ or $\mathrm{S}$ & $\mathrm{C}$ & $\mathrm{C}, \mathrm{S}$ or $\mathrm{T}$ & $\mathrm{C}$ & $\mathrm{S}$ or $\mathrm{T}$ & ND & ND \\
\hline Oxidase & + & + & ND & $\mathrm{V}$ & - & - & $\mathrm{V}$ & ND & - \\
\hline Anaerobic growth & - & ND & - & + & - & - & - & - & + \\
\hline \multicolumn{10}{|l|}{ Growth in the presence of: } \\
\hline $5 \%(\mathrm{w} / \mathrm{v}) \mathrm{NaCl}$ & + & + & - & + & + & + & - & + & + \\
\hline $10 \%(\mathrm{w} / \mathrm{v}) \mathrm{NaCl}$ & + & - & - & $\mathrm{V}$ & - & - & - & - & + \\
\hline \multicolumn{10}{|l|}{ Growth at: } \\
\hline $10^{\circ} \mathrm{C}$ & + & + & + & $\mathrm{V}$ & ND & + & + & + & + \\
\hline $45^{\circ} \mathrm{C}$ & + & + & - & ND & ND & ND & - & ND & + \\
\hline Nitrate reduction & - & + & - & + & + & - & + & - & + \\
\hline \multicolumn{10}{|l|}{ Hydrolysis of: } \\
\hline Aesculin & + & $(-)$ & ND & + & - & + & + & ND & + \\
\hline Casein & + & $\mathrm{v}(+)$ & + & + & + & + & + & - & - \\
\hline Gelatin & - & + & + & + & + & + & + & - & + \\
\hline Starch & + & + & + & $\mathrm{V}$ & + & + & + & - & + \\
\hline Tween 80 & + & $\mathrm{v}(+)$ & - & $\mathrm{V}$ & $\mathrm{V}$ & $\mathrm{ND}$ & + & $\mathrm{ND}$ & $\mathrm{V}(-)$ \\
\hline \multicolumn{10}{|l|}{ Growth on: } \\
\hline D-Galactose & + & ND & - & ND & ND & $(-)$ & ND & ND & ND \\
\hline D-Cellobiose & + & $(-)$ & + & ND & $\mathrm{w}$ & $(-)$ & ND & ND & ND \\
\hline D-Mannose & + & $(-)$ & + & ND & - & $(-)$ & $\mathrm{ND}$ & $\mathrm{ND}$ & ND \\
\hline Sucrose & + & $(-)$ & + & ND & ND & $(-)$ & + & ND & ND \\
\hline Maltose & + & $(-)$ & + & ND & - & $(+)$ & ND & ND & ND \\
\hline Pyruvate & + & $(+)$ & ND & ND & ND & $(-)$ & ND & ND & ND \\
\hline \multicolumn{10}{|l|}{ Acid production from: } \\
\hline D-Glucose & + & $(-)$ & + & + & + & + & + & NG & + \\
\hline Lactose & - & $(-)$ & - & $\mathrm{V}$ & - & $\mathrm{V}$ & - & ND & - \\
\hline D-Mannitol & - & $(-)$ & - & - & $\mathrm{V}$ & + & $\mathrm{V}$ & NG & - \\
\hline D-Mannose & + & $(-)$ & - & $\mathrm{V}$ & $\mathrm{V}$ & $\mathrm{V}$ & + & ND & - \\
\hline D-Xylose & - & $(-)$ & + & - & - & + & + & NG & - \\
\hline DNA $G+C$ content $(\mathrm{mol} \%)$ & 45 & $33 \cdot 9-35 \cdot 0$ & $38 \cdot 6$ & $\begin{array}{c}31 \cdot 7-40 \cdot 1 \\
(35 \cdot 7 \text { or } 36 \cdot 2)\end{array}$ & $40-41$ & $\begin{array}{c}36 \cdot 5-45 \cdot 0 \\
(37 \cdot 3 \text { or } 37 \cdot 6)\end{array}$ & $43-44$ & $\begin{array}{c}34 \cdot 3-35 \cdot 1 \\
(35 \cdot 1)\end{array}$ & 41 \\
\hline
\end{tabular}

${ }^{\star}$ E, Ellipsoidal or oval; C, cylindrical.

$\dagger$ C, Central; S, subterminal; T, terminal; P, paraterminal. 
rRNA gene sequences showed that strain $\mathrm{JG}-30^{\mathrm{T}}$ fell within the radiation of the cluster comprising Bacillus species and Bacillus subtilis, the type species of the genus Bacillus (Fig. 1). Strain JG-30 ${ }^{\mathrm{T}}$ exhibited levels of $16 \mathrm{~S}$ rRNA gene sequence similarity to Bacillus species of less than $95 \cdot 7 \%$ (Fig. 1). Sequence similarities to other species included in the phylogenetic analysis were below $92 \cdot 4 \%$ (Fig. 1). The results obtained from the phenotypic and phylogenetic analyses justify a taxonomic position for strain $\mathrm{JG}-30^{\mathrm{T}}$ as a member of the genus Bacillus. A widely recognized criterion for species definition in current bacteriology (Stackebrandt \& Goebel, 1994) suggests that strains with more than a $3 \%$ difference in $16 \mathrm{~S}$ rRNA gene sequences represent different species. The phylogenetic distinctiveness of strain JG-30 ${ }^{\mathrm{T}}$ warrants separation of this strain from Bacillus species with validly published names (Stackebrandt \& Goebel, 1994). Strain JG$30^{\mathrm{T}}$ can be differentiated from several phylogenetically related Bacillus species by means of some phenotypic characteristics (Table 1). Therefore, on the basis of the data presented, strain JG- $30^{\mathrm{T}}$ should be placed in the genus Bacillus as a novel species, for which the name Bacillus cibi sp. nov. is proposed.

\section{Description of Bacillus cibi sp. nov.}

Bacillus cibi (ci'bi. L. n. cibus - $i$ food; L. gen. n. cibi of food).

Cells are aerobic rods that are $0 \cdot 6-0 \cdot 8 \times 1 \cdot 5-3.5 \mu \mathrm{m}$ in size. Gram-variable. Motile by means of peritrichous flagella. Central or subterminal ellipsoidal endospores are observed in swollen sporangia. Colonies are smooth, glistening, circular to slightly irregular, raised, orange-yellow in colour and 3-4 $\mathrm{mm}$ in diameter after 2 days incubation at $37^{\circ} \mathrm{C}$ on MA. Optimal growth temperature is $37^{\circ} \mathrm{C}$; growth does not occur at 4 and $50{ }^{\circ} \mathrm{C}$. Optimal $\mathrm{pH}$ for growth is 6.5-7.5. Growth is observed at $\mathrm{pH} 5 \cdot 5$ but not at $\mathrm{pH} 5 \cdot 0$. Growth occurs in the presence of $0-12 \%(\mathrm{w} / \mathrm{v}) \mathrm{NaCl}$, with an optimum at $0-1 \% \quad(\mathrm{w} / \mathrm{v}) \quad \mathrm{NaCl}$. Urease-negative. Hypoxanthine, tyrosine and xanthine are not hydrolysed. $\mathrm{H}_{2} \mathrm{~S}$ and indole are not produced. Voges-Proskauer and methyl-red reactions are negative. When assayed with the API $20 \mathrm{E}$ system, arginine dihydrolase, lysine decarboxylase, ornithine decarboxylase and tryptophan deaminase are absent. When assayed with the API ZYM system, alkaline phosphatase, esterase (C4), esterase lipase (C8), naphtholAS-BI-phosphohydrolase and $\beta$-galactosidase are present, but lipase (C14), leucine arylamidase, valine arylamidase, cystine arylamidase, trypsin, $\alpha$-chymotrypsin, acid phosphatase, $\alpha$-galactosidase, $\beta$-glucuronidase, $\alpha$-glucosidase, $\beta$-glucosidase, $N$-acetyl- $\beta$-glucosaminidase, $\alpha$-mannosidase and $\alpha$-fucosidase are absent. Acid is produced from D-fructose, melibiose, D-galactose, D-cellobiose, stachyose, sucrose, maltose, D-trehalose and D-raffinose. Acid is not produced from adonitol, D-sorbitol, myo-inositol, D-ribose, L-arabinose, D-melezitose or L-rhamnose. The following substrates are utilized for growth: D-glucose, D-fructose, D-trehalose, lactose, acetate, succinate and L-malate. D-Xylose, L-arabinose, citrate, benzoate, formate and L-glutamate are not utilized. The cellwall peptidoglycan contains meso-diaminopimelic acid. The predominant menaquinone is $\mathrm{MK}-7$. The major fatty acids are iso- $\mathrm{C}_{15: 0}$ and iso- $\mathrm{C}_{14: 0}$. The DNA G $+\mathrm{C}$ content is $45 \mathrm{~mol} \%$ (determined by HPLC).

The type strain, JG $-30^{\mathrm{T}}\left(=\mathrm{KCTC} 3880^{\mathrm{T}}=\mathrm{DSM} 16189^{\mathrm{T}}\right)$, was isolated from jeotgal, a traditional Korean fermented seafood.

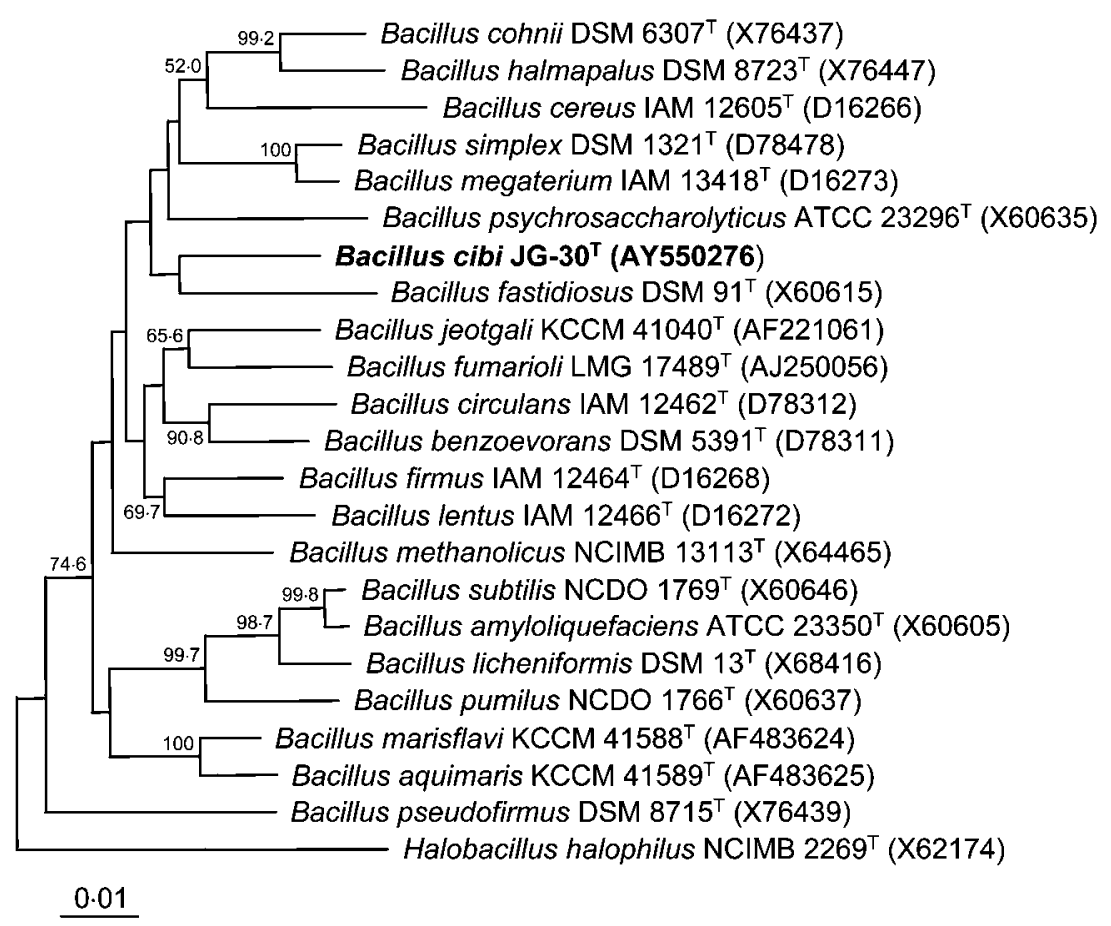

Fig. 1. Neighbour-joining tree, based on 16S rRNA gene sequences, showing the phylogenetic positions of Bacillus cibi JG$30^{\top}$, some Bacillus species and representatives of some other related taxa. Bootstrap values (expressed as percentages of 1000 replications) greater than $50 \%$ are shown at the branch points. Bar, 0.01 substitution per nucleotide position. 


\section{Acknowledgements}

This work was supported by the 21C Frontier Program of Microbial Genomics and Applications (grant MG02-0401-001-1-0-0) from the Ministry of Science and Technology (MOST) of the Republic of Korea.

\section{References}

Baumann, L. \& Baumann, P. (1981). The marine Gram-negative eubacteria; genera Photobacterium, Beneckea, Alteromonas, Pseudomonas, and Alcaligenes. In The Prokaryotes, a Handbook on Habitats, Isolation, and Identification of Bacteria, pp. 1302-1330. Edited by M. P. Starr, H. Stolp, H. G. Trüper, A. Balows \& H. G. Schlegel. Berlin: Springer.

Bruns, A., Rohde, M. \& Berthe-Corti, L. (2001). Muricauda ruestringensis gen. nov., sp. nov., a facultatively anaerobic, appendaged bacterium from German North Sea intertidal sediment. Int J Syst Evol Microbiol 51, 1997-2006.

Claus, D. \& Berkeley, R. C. W. (1986). Genus Bacillus Cohn 1872. In Bergey's Manual of Systematic Bacteriology, vol. 2, pp. 1105-1140. Edited by P. H. A. Sneath, N. S. Mair, M. E. Sharpe \& J. G. Holt. Baltimore: Williams \& Wilkins.

Cohen-Bazire, G., Sistrom, W. R. \& Stanier, R. Y. (1957). Kinetic studies of pigment synthesis by nonsulfur purple bacteria. J Cell Comp Physiol 49, 25-68.

Cowan, S. T. \& Steel, K. J. (1965). Manual for the Identification of Medical Bacteria. London: Cambridge University Press.

De Clerck, E., Rodriguez-Díaz, M., Vanhoutte, T., Heyman, J., Logan, N. A. \& De Vos, P. (2004). Anoxybacillus contaminans sp. nov. and Bacillus gelatini sp. nov., isolated from contaminated gelatin batches. Int J Syst Evol Microbiol 54, 941-946.

Komagata, K. \& Suzuki, K. (1987). Lipids and cell-wall analysis in bacterial systematics. Methods Microbiol 19, 161-203.

Lanyi, B. (1987). Classical and rapid identification methods for medically important bacteria. Methods Microbiol 19, 1-67.

Leifson, E. (1963). Determination of carbohydrate metabolism of marine bacteria. J Bacteriol 85, 1183-1184.

Nielsen, P., Fritze, D. \& Priest, F. G. (1995). Phenetic diversity of alkaliphilic Bacillus strains: proposal for nine new species. Microbiology 141, 1745-1761.

Priest, F. G., Goodfellow, M. \& Todd, C. (1988). A numerical classification of the genus Bacillus. J Gen Microbiol 134, 1847-1882.

Reva, O. N., Smirnov, V. V., Pettersson, B. \& Priest, F. G. (2002). Bacillus endophyticus sp. nov., isolated from inner tissues of cotton plants (Gossypium sp.). Int J Syst Evol Microbiol 52, 101-107.
Sasser, M. (1990). Identification of Bacteria by Gas Chromatography of Cellular Fatty Acids. Newark, DE: MIDI.

Spanka, R. \& Fritze, D. (1993). Bacillus cohnii sp. nov., a new, obligately alkaliphilic, oval-spore-forming Bacillus species with ornithine and aspartic acid instead of diaminopimelic acid in the cell wall. Int J Syst Bacteriol 43, 150-156.

Stackebrandt, E. \& Goebel, B. M. (1994). Taxonomic note: a place for DNA-DNA reassociation and 16S rRNA sequence analysis in the present species definition in bacteriology. Int J Syst Bacteriol 44, 846-849.

Staley, J. T. (1968). Prosthecomicrobium and Ancalomicrobium: new prosthecate freshwater bacteria. J Bacteriol 95, 1921-1942.

Suresh, K., Prabagaran, S. R., Sengupta, S. \& Shivaji, S. (2004). Bacillus indicus sp. nov., an arsenic-resistant bacterium isolated from an aquifer in West Bengal, India. Int J Syst Evol Microbiol 54, 1369-1375.

Tamaoka, J. \& Komagata, K. (1984). Determination of DNA base composition by reverse-phase high-performance liquid chromatography. FEMS Microbiol Lett 25, 125-128.

Täubel, M., Kämpfer, P., Buczolits, S., Lubitz, W. \& Busse, H.-J. (2003). Bacillus barbaricus sp. nov., isolated from an experimental wall painting. Int J Syst Evol Microbiol 53, 725-730.

Yoon, J.-H., Kim, H., Kim, S.-B., Kim, H.-J., Kim, W. Y., Lee, S. T., Goodfellow, M. \& Park, Y.-H. (1996). Identification of Saccharomonospora strains by the use of genomic DNA fragments and rRNA gene probes. Int J Syst Bacteriol 46, 502-505.

Yoon, J.-H., Lee, S. T. \& Park, Y.-H. (1998). Inter- and intraspecific phylogenetic analysis of the genus Nocardioides and related taxa based on 16S rDNA sequences. Int J Syst Bacteriol 48, 187-194.

Yoon, J.-H., Kang, S.-S., Lee, K.-C., Kho, Y. H., Choi, S. H., Kang, K. H. \& Park, Y.-H. (2001a). Bacillus jeotgali sp. nov., isolated from jeotgal, Korean traditional fermented seafood. Int $J$ Syst Evol Microbiol 51, 1087-1092.

Yoon, J.-H., Weiss, N., Lee, K.-C., Lee, I.-S., Kang, K. H. \& Park, Y.-H. (2001b). Jeotgalibacillus alimentarius gen. nov., sp. nov., a novel bacterium isolated from jeotgal with L-lysine in the cell wall, and reclassification of Bacillus marinus Rüger 1983 as Marinibacillus marinus gen. nov., comb. nov. Int J Syst Evol Microbiol 51, 2087-2093.

Yoon, J.-H., Kang, K. H. \& Park, Y.-H. (2003a). Psychrobacter jeotgali sp. nov., isolated from jeotgal, a traditional Korean fermented seafood. Int J Syst Evol Microbiol 53, 449-454.

Yoon, J.-H., Lee, K.-C., Weiss, N., Kang, K. H. \& Park, Y.-H. (2003b). Jeotgalicoccus halotolerans gen. nov., sp. nov. and Jeotgalicoccus psychrophilus sp. nov., isolated from the traditional Korean fermented seafood jeotgal. Int J Syst Evol Microbiol 53, 595-602. 